lection. Pierce, however, continued to act as Baldwin's agent, and after the latter's death in 1807 , he rendered a report on Baldwin's holdings in the town. These were estimated to be 57 lots or tracts totaling 5,815 acres, and were valued at approximately $\$ 9,075$.

But the town is not Loammi Baldwin's only memorial. The famous Baldwin apple was also named after him. Accounts differ materially as to the origin of this name, but the most trustworthy one - although not that contained in the Baldwin Genealogy seems to be that Samuel Thompson, a surveyor, while in Wilmington, Massachusetts, came upon a pasture in which he saw a heavily laden apple tree. As the fruit proved to be delicious, he procured some scions which he set in the trees in his orchard. Soon they bore fruit, and Thompson gave these apples to his friend, Colonel Baldwin. The latter was so delighted with them that Thompson decided to name the variety after the Colonel. And thus once again a friend wrote him an immortal epitaph.

\title{
Dry Goods Trade of 1857
}

Material on the methods of the dry goods business prior to the Civil War is almost as scarce as the proverbial "hen's teeth." It was undoubtedly carried on in all parts of the country and undoubtedly, also, the manner of conducting it changed from time to time, yet the methods of operation and the changes therein have left surprisingly little trace. Something of this history may be secured from the chance remarks of the commercial newspapers of the period, and probably much may be acquired (the work being almost wholly yet to be done) from the account books and letter books of country stores and other mercantile establishments of those days.

Nevertheless, sources such as these are of a cold, impersonal type, and, accordingly, we welcome any scraps from the past which enable us to imagine more actively the ways in which retail business was pursued at that time. Recently there has come into the possession of Baker Library transcripts from letters written in 1857 by Edmund W. Nutter of East Bridgewater, Massachusetts, who in that year, then a boy of sixteen, was serving a sort of apprenticeship in a store at Newburgh, New York, owned by a Mr. Young. The letters were written to his family in East Bridgewater and cover the latter part of the year above mentioned. These documents are mainly of personal character, and the library is indebted for the 
transcription of those parts which pertain to the dry goods business, to Mrs. W. B. Southgate of Marshfield, Massachusetts, a descendant of Mr. Nutter, and at present the possessor of these interesting papers.

Because of their unusual quality, these transcripts are reproduced in full. Particularly interesting are the references to the use of auctions by this retailer as a means of working off "hard stock." Apparently, Mr. Young found it extremely profitable to "dump" these old goods into the territory of his fellow merchants of neighboring towns - an activity which, as the final letter indicates, was far from welcomed by the latter. Surprising to many of us is the fact that here in 1857 , nearly seventy years after the establishment of the American currency system, Newburgh (and indeed a large part of the Hudson River valley) was still using English units "shillings" as the money of account. Again the comments of this sixteen-year-old youth on the crisis of 1857 are notable, while finally a touch of humor is not lacking: one wonders if here we are witnessing the advent of anew vogue in clothing when young Nutter reports of a certain Friday that this little store at Newburgh "sold two hundred and ten pairs of drawers at three shillings a pair in about three hours."

fuly 12,1857

I have been having my room all to myself this last week as Josiah (apparently another clerk in Mr. Young's store) has been to Middletown to sell the old goods there and at Rondout and carry them to some neighboring town to sell off at auction. We received a letter from him yesterday. He will probably be home tomorrow as they had but few goods left yesterday. We have had a very good trade the past week. I sold nearly seventy dollars worth of goods Friday and Saturday.

Father wished me to inquire the price of butter here. We do a good deal of trade with the farmers. I asked one who was in the store the other day what good butter was worth by the tub. He said twenty-one cents. I asked him what first-rate butter was worth, and he answered, "I call our butter as good as any and we have to get twenty-one cents."

Fuly 26,1857

Mother told me in her letter to write if I needed anything. I know of nothing that I want unless it be some shoes. You know that the streets of Newburgh are very steep as you go up. I am obliged to go up and down on my way to and from the store four times a day. It is very bad for shoes as every step which one takes downward forces the foot farther into the shoes. About a week after I came on, I wrenched the heels off of my calf skin shoes while helping to move some very heavy boxes of goods. I would 
not pay three (York) shillings ${ }^{x}$ to have them reheeled so I put on my goatskin ones and they have cracked so badly at the sides that in a week I shall have nothing left but my Congress boots which are too good to wear every day. If you send me on any, send me on a very stout pair.

We have been exceedingly busy the past week. Evivery morning for the last three days, five or six boxes of wet goods have come in which we have had to dry and do up again.' They have sold astonishingly. We have had as much as we could do to measure them off. Gent's drawers, curtain, chintz, English calico, linen, handkerchiefs, cotton, velvet, broadcloth, check palmetto cloth, and I know what not, have been selling as fast as we could do them up. We sold two hundred and ten pairs of drawers at three shillings a pair in about three hours on Friday.

\section{NewBurgh, fuly 26.}

Yesterday we sold three hundred yards of velvet at one shilling a yard before nine in the morning and any quantity of calico during the day at sixpence a yard. I wish you could have seen our counter yesterday evening when it was nearly time to close. I am not stretching the truth when I say it was piled two feet high with a mixture of all kinds of goods which it took three of us nearly an hour in putting up. I expect another lot to come in tomorrow. I am going to sleep in the store this week as the person who opens the store has gone home to spend his vacation.

\section{September 20,1857}

It is still dull in E. B. (East Bridgewater), I suppose, quite different from Newburgh. I wish the steam works might be started again and the place become enlivened. ${ }^{3}$ I should like then to come home and help Newton in the store. I think that now I am sufficiently competent to take charge of the dry goods department. It seems to me that we might sell a great many goods if E. B. should ever become enlivened again. I wish Father would try to buy in New York at auction. Goods are so very cheap there. Mr. Chandler has bought six cases of muslins which are to come in tomorrow morning and I shall have enough to do. I mean to learn all that I can concerning dry goods between this and the time I come home. I have a good chance to learn; there is such a variety of goods in the store. At present there is but little trade, but the fall trade will open soon and we shall be busy enough. Trade will not be so large this fall on account of the scarcity of money. The farmers here will hold on to their crops and will not get so much as they expect, so of course will not trade so much. I suppose you have read of the loss of the U.S. mail steamer, Central America. We have had further particulars today. The number lost was three hundred

I The "York shilling" was also known as a "bit" and had the value of an eighth of a dollar.

2 Seemingly "wet goods" are here goods damaged by water during shipment. The casualness of Nutter's reference to this condition of the goods is illuminating.

${ }^{3}$ Probably a nail mill. 
and thirteen persons, not so many as was feared. The money amounted to a million and a half. The brokers in Wall Street will feel it some probably.'

\section{Oct. 16,1857}

I received your letter last Tuesday and was glad to find that it was concerning my return home. I have been talking with Mr. Young this afternoon. He says in regard to the present engagement that he will pay my board as he agreed with you to do. He says he does not think it would be worth while for me to come back again if you want me in the Spring. I said nothing to him as to what he would give me if I should come back again as I hardly think he would give me what you mentioned in your letter.

There is one clerk in the store who is about my age who only gets his board now and he has been here three years; he is a very good clerk too. There are two others here two or three years older who get only the same. The best clerk gets only four hundred dollars.

All the banks suspended here last Wednesday and since then business has been better although it is not half so good as it usually is in this month. We have been having an auction at Fishkill for the last three evenings; the amount taken is about one hundred and twenty-five dollars an evening. The goods which were sent over were about the poorest lot I ever saw. Mr. Chandler is auctioneer; he is a very good one. Some of the goods bring nearly twice as much as we ask for them at private sale, a very respectable profit. We have an auction at Fishkill the first three days of this week and next week we have an auction at Cold Spring. We have about a thousand dollars worth in all. Mr. Chandler says he is going to sell off all the hard stock at auction. He takes all kinds of money in exchange for them. I saw in the paper that the Boston banks had suspended. It is a good thing. I hope business will be better now.

$$
\text { Nov. } 1,1857
$$

Josiah did not come home until this morning. He says that the auction is ended. They have sold all but the silks and the shawls which they are going to bring back. There will be nothing out of the regular line of business this coming week and as business is dull now, Mr. Young says he can spare me now as well as any time before Thanksgiving. ... Trade the last week has been rather dull. The auction at Fishkill village did not turn out as well as the one at the landing. They have sold nearly three times as many goods at the last auction, but they did not bring comparatively such high prices. Chandler would have come back Thursday had it not been for one of the merchants over there who tried to drive him away and start an auction himself but he couldn't come it.

${ }^{1}$ The "Central America" went down with much gold on board. Total loss was estimated at two and a half million dollars, while only half a million insurance was carried. 